\section{秋田県皆瀬川上流 木地山付近の地形}

\section{四辺 健一一水照裕}

焳物川の支流皆瀬川上流の小安温泉西方に, こけしで有名な木地山を中心に，標高 300〜 $600 \mathrm{~m}$ の高原状の地形が厸く展開する。地質は 石英安山岩抒よび同質凝死岩が下部の中新世に 属する三途川層（板状砂岩凝戻筫泥岩）を覆ってい る。三途川層愹城県鬼首盆地の赤沢層や宮沢 層に対比される中新世最上部の湖成層とされて いる（加藤・島田 1953）。このような地質で棈成 された高原状の地域に（亿）桁倉沼・田螺沼・ 板戸沼・貝沼等の湖沼や陷地，(口) その周辺 の流れ山状の小丘群，叫绝山周辺の岩塊流。 などの特殊な地形群がみられる。これらの地形 に関专る報告は吉村信吉 (1935) に上る湖沼学的 研究が岁るにすぎない。筆者等は1965 年 9 月, 2 日間の概査を試久た。
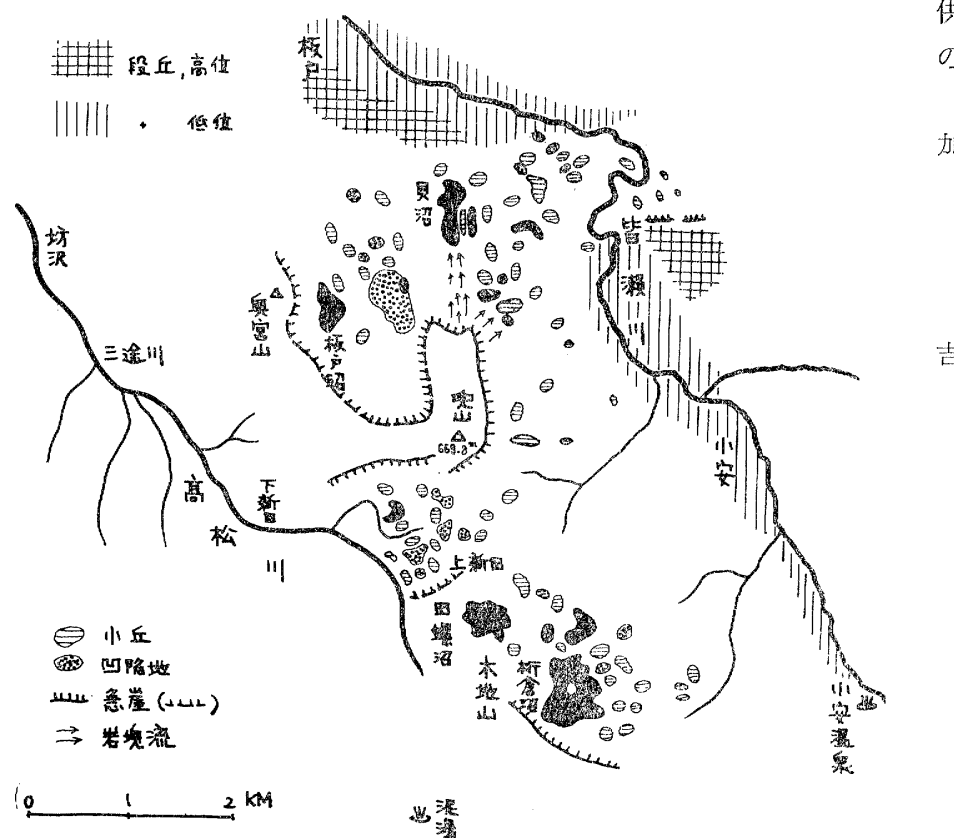

存在から考えて, 大
成因之考光られる。

罗山の北打よび東には上述の小丘群の上に, 新しいが現成とに思劣ない，岩塊流が女る。こ れは呪山の東部々北部に露出する石英安山岩の 柱状節理から供給されたもので只ことは明瞭 であり, 照山北方の岩㱱流の先端は貝沼の南岸 に亦で達し, 岩塊の最大径俚 $10 \mathrm{~m}$ 以上も女る。

罗山北東与の地しり・山崩れによる押出し地 形は皆瀬川の河岸段丘を被覆しており，さらに その上に岩塊流が来ていることは，それらの時 代決定々気候变化の時期の関係などの問題を提 供するものであって, 甚だ與味 のある地形と思われる。

(1966.9. 27 受理)

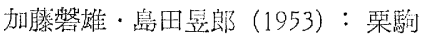
火山西㯟緑色凝死岩相地域の地質 字よび特に三途川・鬼首盆地の湖 成堆積檿について 岩鎕 37178 $\sim 190$

吉村信吉（1934）：秋田罧雄腾郡枌 㝓沼, 貝沼湖群の湖沼学的予察研 究 地評 $10667 \sim 687,787 \sim 798$

\title{
Topography of the Kijiyama Highland, Akita Prefecture
}

\section{Ken-ichi TANABE and Yutaka MIZUNO}

There are six small lakes and many hillocks in the Kijiyama Highland, 300-600 m above the sea level in the southeastern part of Akita prefecture. These lakes and hillocks were formed by an ancient landslide in the area of the Miocene Sanzugawa lucustrine deposits. To the south of Lake Kainuma, boulders are flown down the northern and the eastern slopes of Mt. Kabuto $(669.8 \mathrm{~mm}$ ) (arrows in illsutration), covering the landslide materials. Landslide materials and boulders cover the terraces of the Minase river. These relation presents an interesting problem on the paleoclimatology of the area. 